\title{
Oxidation mechanism and overall removal rates of endocrine disrupting chemicals by aquatic plants
}

\author{
A.R. Reis ${ }^{a}$, K. Tabei ${ }^{b}$, and Y. Sakakibara
}

a Department of Soil Science, Federal University of Lavras, Lavras-MG 37200-000, Brazil.

${ }^{b}$ Department of Civil and Environmental Engineering, Waseda University, 169-8555, 3-4-1

Okubo, Shinjuku, Tokyo, Japan. *E-mail: andrereis@dcs.ufla.br ; sakaki@waseda.jp 


\begin{abstract}
The purpose of this study was to evaluate experimentally and theoretically the oxidation mechanisms and overall removal rates of phenolic endocrine disrupting chemicals (EDCs) by aquatic plants. EDCs used in this study were bisphenol-A (BPA), 2,4dichlorophenol (2,4-DCP), 4-tert-octylphenol (4-t-OP), and pentachlorophenol (PCP). Referring to reported detection levels in aquatic environments and contaminated sites, the feed concentration of each EDC was set from 1 to $100 \mu \mathrm{g} / \mathrm{L}$. Experimental results showed that, except for PCP, phenolic EDCs were stably and concurrently removed by different types of aquatic plants over 70 days in long-term continuous treatments. Primal enzymes responsible for oxidation of BPA, 2,4-DCP, and 4-t-OP were peroxidases (POs). Moreover, enzymatic removal rates of BPA, 2,4-DCP, and 4-t-OP by POs were more than 2 orders of magnitude larger than those by aquatic plants. Assuming that overall removal rates of EDCs are controlled by mass transfer rates onto liquid films on the surface of aquatic plants, an electrochemical method based on the limiting current theory was developed to measure the mass transfer rates of EDCs. Because of extremely large removal rates of EDCs by POs, observed removal rates by aquatic plants were in reasonably good agreement with calculated results by a mathematical model developed based on an assumption that mass transfer limitation is a rate-limiting step.
\end{abstract}

Keywords: Endocrine disrupting chemicals; hydrogen peroxide; peroxidase; biological Fenton reaction, phytoremediation 


\section{Introduction}

Environmental pollutants such as EDCs have been detected in aquatic environment, and their effects on human health and aquatic life forms have received considerable attention [1]. Especially, the estrogenic effects of BPA, 4-t-OP, and estrogens such as estrone (E1), 17ß-estradiol (E2), and 17a-ethinylestradiol (EE2) were identified for aquatic lives [1, 2]. In addition, there are suspected EDCs such as PCP and 2,4-DCP with potential estrogenic activities. Concentration ranges of these EDCs were reported as 0.5 to $21 \mu \mathrm{g} / \mathrm{L}$ for BPA in stream/river [3], $5 \mathrm{ng} / \mathrm{L}$ to $4 \mu \mathrm{g} / \mathrm{L}$ for 4 -t-OP in rivers [4], 26 $\mathrm{ng} / \mathrm{L}$ to $20 \mu \mathrm{g} / \mathrm{L}$ for $2,4-\mathrm{DCP}$ in rivers [5], and 2 to $82 \mathrm{ng} / \mathrm{L}$ for natural and synthetic estrogens in effluents from sewage treatment plants [6]. Higher levels of EDCs up to 7 and $17 \mathrm{mg} / \mathrm{L}$ for phenols and BPA were found in leachates of waste landfills, respectively $[7,8]$. Because of identified and suspected endocrine disrupting effects, effective methods for removal of these EDCs from contaminated sites are required.

Former studies on EDCs removal demonstrated the possibility of EDCs treatments by plants, plant tissues, and plant enzymes. Table 1 shows an example of these studies, demonstrating that EDCs such as BPA, 2,4-DCP, 4-t-OP, NP, E1, E2, and EE2 could be removed by enzymes such as peroxidases (POs) [9, 10, 11, 19], laccase (LAC) [12, 13], polyphenol oxidase (PPO) [10, 14], and glutathione S-transferase (GST) [15] as well as plant cells or tissues containing enzymes $[16,17,18]$. In addition, some researchers [9, 18] confirmed that treatment of phenolic EDCs by plant enzymes or plant tissues was effective to eliminate estrogenic activity from contaminated sites. As shown in Table 1, most studies on EDCs treatment have been conducted based on batch experiments with relatively high concentrations of EDCs (i.e. $\mathrm{mg} / \mathrm{L}$ level) when compared with observed levels in aquatic environments. Batch experiments could indicate the possibility of removing EDCs, however, continuous performance and/or stability have not been well known. Furthermore, studies focusing on mechanisms and kinetics of EDCs removals have not been conducted extensively; and therefore, rational operation and design conditions with information on appropriate plants have not been available.

This study focused on oxidation mechanisms and removal rates of trace EDCs by aquatic plants. Continuous treatments of BPA, 2,4-DCP, 4-t-OP and PCP were conducted using different aquatic plants, and the stability and removal rates were 
investigated. In our previous study [19], EDCs concentration was set continuously at 100 $\mu \mathrm{g} / \mathrm{L}$. However, in this study, the feed concentration of BPA, 2,4-DCP, 4-t-OP and PCP was set in the range of 1 to $100 \mu \mathrm{g} / \mathrm{L}$ to investigate the removal ability of aquatic plants at different influent concentration. In addition, enzymatic removal rates of EDCs were measured to elucidate primal enzymes and reactions responsible for the EDCs removal in phytoremediation process. The same measurements and comparison were made for removals of estrogens such as E1, E2, and EE2. To better understand the overall removal rates by aquatic plants, an electrochemical method based on the limiting current theory was developed to measure the mass transfer rates of EDCs. A mathematical model was developed based on an assumption that overall removal rates of EDCs are controlled by the mass transfer rates in liquid film onto the surface of aquatic plants, and comparisons of calculated and observed results were made to evaluate the net removal rates of EDCs by aquatic plants.

\section{Materials and methods}

\subsection{Aquatic plants}

Aquatic plants used in this study were floating plants, Amazon frogbit (Limnobium laevigatum), Giant Duckweed (Spirodela polyrhiza), Duckweed (Lemna aoukikusa), Liver wort (Ricciocarpos natans), and Crystalwort (Riccia fluitans); submerged plants, Willow Moss (Fontinalis antipyretica), Hydrilla (Hydrilla verticillata), Pondweed (Potamogeton oxyphyllus), Hornwort (Ceratophyllum demersum); and an emergent plant, Watercress (Nasturtium officinale).

Enzyme activities in aquatic plant tissues were measured according to previously studies [13, 33, 34] and were listed in Table 2 with parameters such as specific surface area (a), endogenous $\mathrm{H}_{2} \mathrm{O}_{2}$ level, and water content. Enzymatic activities were converted to number of units $(U)$ based on extinction coefficient such as $26.6 \mathrm{mM} / \mathrm{cm}$ for POs, $1.42 \mathrm{mM} / \mathrm{cm}$ for PPOs, $3.6 \mathrm{mM} / \mathrm{cm}$ for LAC, and $9.6 \mathrm{mM} / \mathrm{cm}$ for GST. One unit of enzyme activity $(U)$ represents the amount of enzyme catalyzing $1 \mu \mathrm{moL}$ of a reference substrate per $1 \mathrm{~min}$ in the corresponding enzymatic reaction. 


\subsection{Continuous treatments of EDCs by aquatic plants}

Referring to reported detection levels in contaminated sites, the feed concentration of BPA, 2,4-DCP, 4-t-OP and PCP was set in the range of 1 to $100 \mu \mathrm{g} / \mathrm{L}$. The stock solutions of each EDC were prepared and dissolved in a diluted Hoagland solution.

Continuous treatments of BPA, 2,4-DCP, 4-t-OP and PCP were conducted using an experimental apparatus illustrated in Fig. 1, where each plant was cultivated in glass vessels (effective liquid volume was $5 \mathrm{~L}$ ). All vessels were maintained under intermittent illumination, which consisted of light and dark periods of $16 \mathrm{~h}$ and $8 \mathrm{~h}$, respectively. The illumination during the light period was controlled at 3000 lux and was provided by white fluorescent lamps. The flow rate of the feed solution was set at $1.92 \mathrm{~L} /$ day (corresponding to HRT $=2.6$ days) using peristaltic pumps.

Every experiment and analysis was conducted at a room temperature $\left(25^{\circ} \mathrm{C}\right)$. In continuous experiments, the amount of aquatic plant was set at $5 \mathrm{~g}-\mathrm{FW}$ (fresh weight)/L and the feed solution was prepared every 5 days. The fresh biomass of aquatic plants was monitored and the excess over than $5 \mathrm{~g}-\mathrm{FW} / \mathrm{L}$ was removed. In parallel to the continuous experiments, a blank test without any aquatic plant was conducted as a reference. After the end of the continuous treatment, plants were taken out from the vessels and the amount of EDCs accumulated in their tissues was analyzed.

To investigate the possible effect of microorganisms on EDCs degradation, part of aquatic plants were collected from the vessels after 35 days of operation, and were disinfected with sodium hypochlorite (5\%) for $10 \mathrm{~min}$ as described by Toyama et al. [13], and afterwards, washed with distilled water several times to avoid physiological damage. After that, batch treatments of BPA, 2,4-DCP, 4-t-OP and PCP were conducted and compared with those by undisinfected aquatic plants.

\subsection{Removal rates of EDCs by extracted crude enzymes}

In order to determine the primal enzymes in the EDC treatments, different fractions of crude POs were extracted from homogenized aquatic plants so as to conduct further in vitro batch treatments of phenolic EDCs. The following extraction steps were carried out at $4^{\circ} \mathrm{C}$. For each enzyme, the aquatic plant tissues were homogenized in a buffer solution (buffer volume $(\mathrm{mL}$ ):fresh weight $(\mathrm{g})=1: 1)$ using a mortar with a pestle. The PO 
fractions, soluble PO (SPO), ionically cell wall-bound PO (IPO), and covalently cell wallbound $\mathrm{PO}$ (CPO) were extracted at $\mathrm{pH} 6.0$ in $50 \mathrm{mM}$ tris-maleate, $0.2 \mathrm{M} \mathrm{CaCl}_{2}$, and 40 $\mathrm{mM}$ tris-maleate buffer as described in a previous study [34]. The homogenate was centrifuged at $10000 \times \mathrm{g}$ for $30 \mathrm{~min}$, and the supernatant was used for the measurement of enzyme activities as well as for the in vitro treatment of EDCs. In order to simulate the degradation of phenolic EDCs by enzymes in plant cells, each crude enzyme fraction of POs, PPO, LAC and GST was extracted according to previous studies [13, 33, 34]. To avoid any interference, in vitro treatments of phenolic EDCs were performed with a buffer for each enzyme. In this study, all enzymatic degradation reactions were performed in a capped erlenmeyer flask. Initial concentration of each phenolic compound (BPA, 2,4-DCP, 4t-OP, PCP, E1, E2 and EE2) was individual set at $100 \mu \mathrm{g} / \mathrm{L}$, and $1 \mathrm{~mL}$ of each crude enzyme was added separately in $40 \mathrm{mM}$ tris-maleate $(\mathrm{pH} \mathrm{6.0})$ and $0.15 \mathrm{mM} \mathrm{H}_{2} \mathrm{O}_{2}$. The final volume was completed to $100 \mathrm{~mL}$ and the enzymatic reactions, performed at $25^{\circ} \mathrm{C}$, were stopped after $3 \mathrm{~h}$. EDCs concentrations were measured in triplicate and a control experiment without crude enzyme was conducted as reference.

\subsection{Measurements of mass transfer rates}

The mass transfer rates of EDCs were experimentally measured and analyzed using an electrochemical technique based on the limiting current theory proposed in our previous study [35]. The experimental apparatus was set at the same conditions as described in continuous experiment. The surface of aquatic plant was sprayed with an electromagnetic paint (MAC-115 spray, Yugen-Mac Corporation). After the paint dried, oxidation-reduction potential (ORP) and $\mathrm{pH}$ probes were installed in the vessel, and the potential and current applied were monitored using a multimeter. The experiment was carried out using an electrolyte solution of $10 \mathrm{mM}$ copper sulfate and $50 \mathrm{mM}$ sulfuric acid diluted in deionized water.

The electric current was increased in small increments until a well-defined decrease in the ORP was observed. At this point, the limiting current was reached [35]; and the thickness of liquid film $(\delta)$ and the mass transfer coefficient of EDCi $(k L i)$ could be analyzed by the follow equations: 


$$
\begin{gathered}
\delta=\frac{2 F D_{C u^{2+} C_{C u^{2+}}}}{i_{l i m}} \\
k_{L i}=\frac{D_{E D C i}}{\delta}
\end{gathered}
$$

Where $\mathrm{i}$ lim is the limiting current density $\left(\mathrm{A} / \mathrm{cm}^{2}\right), \mathrm{F}$ is Faraday constant $\left(9.648 \times 10^{4}\right.$ $(\mathrm{C} / \mathrm{mol})), \mathrm{Dcu}^{2+}$ is the molecular diffusion coefficient of $\mathrm{Cu}^{2+}\left(\mathrm{cm}^{2} / \mathrm{s}\right), \mathrm{Cu}^{2+}$ is the bulk concentration of $\mathrm{Cu}^{2+}$ (i.e. $10^{-5} \mathrm{~mol} / \mathrm{cm}^{3}$ in this study), and DEDCi is the molecular diffusion coefficient of component $\mathrm{i}$ of EDCs. The diffusion coefficient of $\mathrm{Cu}^{2+}$ used to calculate the thickness is $0.72 \times 10^{-5} \mathrm{~cm}^{2} / \mathrm{s}$ [36]. Molecular diffusion coefficients of EDCs were estimated using Wilke and Chang relationship [37] as follows: $\left(\mathrm{cm}^{2} /\right.$ day $)$ BPA $=0.195$; $2,4-\mathrm{DCP}=0.281 ; 4-\mathrm{t}-\mathrm{OP}=0.189 ; \mathrm{PCP}=0.226 ; \mathrm{E} 1=0.178 ; \mathrm{E} 2=0.211 ;$ and $\mathrm{EE} 2=$ 0.167 .

\subsection{Chemical analysis of phenolic EDCs and estrogens}

Chemical analysis of EDCs and estrogens were referred to tentative investigation manual [38]. In the analysis of aqueous solutions of BPA, 2,4-DCP, 4-t-OP, and PCP, $100 \mathrm{~mL}$ of water samples were extracted two times with $10 \mathrm{~mL}$ of dichloromethane 5000 (Wako Pure Chemical Industries, Ltd.), after adding $5 \mathrm{~g}$ of $\mathrm{NaCl}, 0.2 \mathrm{~mL}$ of $1 \mathrm{M} \mathrm{HCl}$ solution, and $5 \mu \mathrm{L}$ of surrogate. The surrogate was spiked to confirm the analytical recoveries and precision. The extracted samples were then transferred to capped erlenmeyer flasks, and $3 \mathrm{~g}$ of sodium sulfate was added and kept for over $12 \mathrm{~h}$. Thereafter, trimethylsilyl (TMS) derivatives were obtained and were measured using GC/MS (Shimadzu QP5050A).

The standards of $E 1, E 2, E E 2$, and $17 \beta$-estradiol $\left(16,16,17-d_{3}\right)$ were purchased from Wako Chemicals (Japan). The internal standard $17 \beta$-estradiol $\left(16,16,17-\mathrm{d}_{3}\right)$ was spiked in water samples to confirm analytical recoveries and precision. In solid phase extraction of the estrogens, C18 cartridges (Sep-Pak Plus, Waters) were conditioned sequentially with $5 \mathrm{~mL}$ of acetone, $5 \mathrm{~mL}$ of methanol, $5 \mathrm{~mL}$ of pure water (3 times), water samples, 5 $\mathrm{mL}$ of pure water, and $5 \mathrm{~mL}$ of hexane. The working solution was extracted using $5 \mathrm{~mL}$ 
of ethyl acetate/acetone $(1: 1 / \mathrm{v}: \mathrm{v})$ through the cartridges. The final sample extracts were transferred to autosampler vials and evaporated to dryness with a gentle stream of nitrogen. After the addition of derivatives such as $5 \mu \mathrm{L}$ of naphthalene, $25 \mu \mathrm{L}$ of pyridine and BSTFA + $1 \%$ TMCs for E1 and E2 analysis, and $130 \mu \mathrm{L}$ of pyridine and BSTFA + $1 \%$ TMCs for EE2, the vials were heated at $70^{\circ} \mathrm{C}$ for 30 minutes. The silylated derivatives obtained were analyzed by GC-MS.

Phenolic EDCs accumulated in aquatic plant tissues were also measured. The procedure extractions of EDCs were carried out after the following pretreatments. First, the aquatic plants were washed with distilled water, submerged in liquid nitrogen, and ground in methanol using a mortar and a pestle. After that, the EDCs were extracted with dichloromethane, and the analysis was performed in the same procedure as water samples.

\subsection{Endogenous $\mathrm{H}_{2} \mathrm{O}_{2}$}

The endogenous $\mathrm{H}_{2} \mathrm{O}_{2}$ concentration in aquatic plants was measured according to Okuda et al. [39]. Aquatic plant samples (0.3 g-FW) were ground in liquid nitrogen using a mortar and pestle, and the finely powdered material obtained was mixed with $1 \mathrm{~mL}$ of $0.2 \mathrm{M}$ perchloric acid. The mixture was centrifuged at $12000 \times \mathrm{g}$ and $4^{\circ} \mathrm{C}$ for $15 \mathrm{~min}$. Afterwards, by adding horseradish PO (Wako Pure Chemicals) and prescribed chemicals, $\mathrm{H}_{2} \mathrm{O}_{2}$ concentration was measured at $590 \mathrm{~nm}$ using a standard calibration curve. The endogenous $\mathrm{H}_{2} \mathrm{O}_{2}$ concentration was expressed in $\mu \mathrm{mol} / \mathrm{kg}-\mathrm{FW}$.

\subsection{Histochemical localization of $\mathrm{POs}$ and $\mathrm{H}_{2} \mathrm{O}_{2}$}

Transverse sections of the stem of $C$. demersum were obtained using a freehand microtome. After that, the histochemical localization of POs was conducted by placing a sample in $40 \mathrm{mM}$ tris maleate buffer containing $84 \mathrm{mM}$ guaiacol and $3 \mathrm{mM} \mathrm{H}_{2} \mathrm{O}_{2}$. The enzymatic reaction for staining the sample was carried out in $1 \mathrm{~min}$, where PO activity in plant cell structures was recorded as a brown color formation. From the stained sample, we found that POs were located in almost every part of aquatic plants; therefore, another sample was also stained with guaiacol for the localization of endogenous $\mathrm{H}_{2} \mathrm{O}_{2}$. As reference, treatments without $\mathrm{H}_{2} \mathrm{O}_{2}$ and guaiacol were conducted and their results 
were compared with the stained samples. The sections of the samples were washed with distilled water and were observed using a microscope (Olympus BX60).

\section{Results and discussion}

\subsection{Continuous treatments}

Figs. 2 (A)-(D) show experimental results of continuous treatments of BPA, 2,4-DCP, 4-t-OP and PCP by aquatic plants such as $N$. officinale, $C$. demersum, and $R$. natans. Influent concentration of each EDC was changed in a stepwise manner from $10 \mu \mathrm{g} / \mathrm{L}$ to 1,100 , and $10 \mu \mathrm{g} / \mathrm{L}$ to evaluate the ability of aquatic plants to remove BPA, 2,4-DCP, 4t-OP and PCP at different influent concentrations. No removals of EDCs were observed in blank experiments (no aquatic plants). During the first 44 days, effluent concentrations of BPA, 2,4-DCP, and 4-t-OP declined quickly, approaching steady-state values. Similar results were obtained using different aquatic plants for long-term continuous treatments of EDCs in our previous studies [19, 25]. These results demonstrated that very stable and concurrent removals of EDCs except PCP were achieved by aquatic plants.

During days 45 and 56, the effluent concentrations of BPA and 4-t-OP from the vessel of $C$. demersum became larger than the influent concentration of $1 \mu \mathrm{g} / \mathrm{L}$; however, in the subsequent treatment the concentrations became lower than the influent concentration $(100 \mu \mathrm{g} / \mathrm{L})$ during days 57 and 65 . From these results, it could be seen that when influent concentration became very low, longer periods of treatment would be required to reach steady state conditions. After day 66, the influent concentration was returned to $10 \mu \mathrm{g} / \mathrm{L}$ and the effluent concentrations of most EDCs became similar to levels observed during the first 44 days. Regarding the treatment of PCP, no significant removal was observed in any vessels of aquatic plants. This compound was used as a pesticide and its persistency and toxicity were reported in the literature [40]. Therefore, it is considered that PCP is too refractory to be decomposed or oxidized by aquatic plants or enzymes.

To evaluate the possible influence of microorganisms associated with aquatic plants, batch treatments of BPA, 2,4-DCP, 4-t-OP and PCP by disinfected plants (L. laevigatum and S. polyrhiza) were conducted and compared with those by undisinfected plants. As shown in Figs. $3(A)$ to (D), no significant differences on BPA, 2,4-DCP, 4-t-OP, and 
PCP removals were observed between disinfected and undisinfected plants. In a comparison using S. polyrhiza, Hoang et al. [41] also reported no significant effect of the plant-bacteria association on the removals of BPA, 2,4-DCP and NP. From these results, it was thought that continuous and stable removals of BPA, 2,4-DCP, and 4-t-OP were achieved by aquatic plants as shown in Figs. 2 (A)-(C).

After 70 days of operation in the continuous experiments, aquatic plants were taken out and amounts of EDCs accumulated in plant tissues were analyzed. However, the amounts were less than $5 \%$ of total EDCs removed in the experiment (data not shown). Referring to former studies shown in Table 1, it is considered that except for PCP, the EDCs removed were oxidized or degraded by certain enzymes in aquatic plants.

To evaluate removal performances of EDCs by different aquatic plants, the specific removal rates based on the wet surface areas of aquatic plants were calculated by:

$$
r_{\text {surface }}=\frac{\left(\Delta E D C_{\text {plant }}-\Delta E D C_{\text {blank }}\right)}{a \times X \times H R T}
$$

Where,

$r_{\text {surface }}=$ specific removal rate of EDCs based on the wet surface area of aquatic plant $\left(\mu \mathrm{g} / \mathrm{cm}^{2} /\right.$ day $)$,

$\triangle \mathrm{EDC}_{\text {plant }}=$ difference of EDC concentrations between influent and effluent at steady state condition in vessel of aquatic plant $(\mu \mathrm{g} / \mathrm{L})$,

$\triangle \mathrm{EDC}_{\text {blank }}=$ difference of EDC concentrations between influent and effluent of blank vessel at steady state condition $(\mu \mathrm{g} / \mathrm{L})$,

$\mathrm{HRT}=$ hydraulic retention time (day),

$\mathrm{X}=$ biomass concentration $(\mathrm{g}-\mathrm{FW} / \mathrm{L})$,

$a=$ specific surface area of aquatic plant $\left(\mathrm{cm}^{2} / \mathrm{g}-\mathrm{FW}\right)$.

Observed removal rates of BPA, 2,4-DCP, 4-t-OP and PCP are shown against effluent concentration $\left(\mathrm{C}_{\mathrm{EDC}}\right.$ ) in Fig. 4, where the removal rates at influent concentrations of 10 and $100 \mu \mathrm{g} / \mathrm{L}$ in this study, as well as results observed in our previous study [19] 
were also plotted. Data at an influent concentration of $1 \mu \mathrm{g} / \mathrm{L}$ was not adopted, because it was considered that the steady state condition was not reached.

As shown in Fig. 4, except for PCP the specific removal rates of EDCs, rsurface $_{\text {were }}$ in the range of 0.02 to $0.66\left(\mu \mathrm{g} / \mathrm{cm}^{2} /\right.$ day $)$ and were similar regardless of different species or morphologies of aquatic plants. The specific removal rate based on biomass of aquatic plants can be obtained by multiplying the specific surface area $(a)$ of aquatic plant to $r_{\text {surface }}$ defined by Equation (3). Corresponding specific removal rates ranged from 0.54 to $31(\mu \mathrm{g} / \mathrm{g}-\mathrm{FW} /$ day $)$. Furthermore, the specific removal rates tended to increase with increasing bulk or effluent concentration of EDCs. The removal rates of PCP (plotted by $\boldsymbol{\Delta}$. officinale, $\bigcirc \mathrm{C}$. demersum, and $\bullet R$. natans) in continuous treatments were very low and 1 or 2 orders of magnitude smaller than those of BPA, 2,4$\mathrm{DCP}$, and 4-t-OP. This happens because aquatic plants show no ability to remove PCP from aqueous solutions.

\subsection{In vitro phenolic EDCs treatment by extracted crude enzymes}

In order to evaluate the mechanism or primal enzymes responsible for the EDCs removals, batch treatments of BPA, 2,4-DCP, 4-t-OP, and PCP, as well as estrogens such as E1, E2, and EE2 were conducted using crude enzymes extracted from aquatic plants. Table 3 shows observed removal efficiencies, where treatment or reaction times for POs and other enzymes (i.e. PPO, GST, and LAC) were set at 3 and $12 \mathrm{~h}$, respectively. Regardless of the reaction times, relatively higher removal efficiencies of BPA, 2,4-DCP, 4-t-OP, E1, E2 and EE2 were observed for POs, while poor efficiencies for PPO, GST, and LAC. Similar results for in vitro phenolic EDCs treatments by crude enzyme extracted from different aquatic plants were observed in our previous study [19]. The removal efficiency by POs varied depending on EDCs and estrogens. For example, estrogens such as E1, E2 and EE2 were removed $100 \%$ by POs. It is interesting to note that total removal efficiencies of most EDCs except PCP by POs were close to or more than $100 \%$. Comparing Tables 2 and 3, we found that plants with higher POs activities, such as $C$. demersum and $R$. fluitans, showed higher removal efficiencies in the enzymatic in vitro treatments. 
Regarding PCP, removal efficiencies were relatively smaller in comparison with other EDCs. In addition, in the cases of IPO and CPO, relatively larger efficiencies up to $50 \%$ were observed. The reason for these removals was not known, but as no significant removal of PCP was observed in continuous treatments (Fig. 2), we suppose that the removals were mainly attributable to adsorption to some constituents in extracts. This is supported by the work of Song and Huang [42], who reported that PCP was removed from about $30 \%$ of its initial concentration by sorption processes in a batch treatment using L. polyrhiza.

The results mentioned above indicated that primal enzymes responsible for the treatments of BPA, 2,4-DCP, and 4-t-OP, E1, E2, and EE2 were POs that catalyze the following oxidation reaction:

$$
\text { Endogenous } \mathrm{H}_{2} \mathrm{O}_{2}+\text { EDCs or estrogens } \stackrel{\text { Peroxidases }}{\longrightarrow} \text { Product }+\mathrm{H}_{2} \mathrm{O}
$$

According to Equation (4), endogenous $\mathrm{H}_{2} \mathrm{O}_{2}$ concentration in aquatic plants is a key substance for EDCs degradation inside plants. During oxidation processes, phenolic compounds were converted catalytically to phenoxy radicals, which polymerize EDCs and then formed less soluble products in cell or water $[9,10]$. On the other hand, regarding the final products of EDCs, a study [14] reported that BPA was degraded to $\mathrm{CO}_{2}$ and $\mathrm{H}_{2} \mathrm{O}$ via two phenolic intermediates by Caragana chamlagu, while different products such as carbohydrate conjugates [11], glycosylation products [43], polymer and 4-isopropenylphenol [44], and hydroxylation products [11] were reported by different researches using different plant species, plant tissue or plant enzyme. Further studies will be needed to identify final products formed inside aquatic plants.

To analyze the relations between the removal rates of EDCs by aquatic plants (Fig. 4 ) and by crude enzymes (Table 3), the specific removal rates by PO enzymes were calculated by:

$$
r_{\text {enzyme }}=\frac{\left(\Delta E D C_{\text {plant }}-\Delta E D C_{\text {blank }}\right)}{a \times X^{*} \times \Delta T}
$$


Where, $X^{*}$ is a corresponding biomass concentration of aquatic plant (10 g-FW/L in this study) from which crude enzymes (i.e. POs) were extracted, and $\Delta T$ is the treatment time (3 $\mathrm{h}$ in the case of POs).

The maximum values of the specific rates of each EDC and estrogen calculated by Equation (5) were in the range of 6 to $70 \mu \mathrm{g} / \mathrm{cm}^{2} /$ day, which were almost 2 orders of magnitude larger than the overall removal rates by aquatic plants. This indicates that the oxidation of EDCs and estrogens by POs was not the rate-limiting step.

\subsection{Histochemical localization of $\mathrm{POs}$ and endogenous $\mathrm{H}_{2} \mathrm{O}_{2}$}

In the histochemical localization using guaiacol and $\mathrm{H}_{2} \mathrm{O}_{2}$, it is possible to visualize the location of POs in plant cells. The results for $C$. demersum are shown in Figs. 5 (A) to $(C)$. Looking at the sections of stem (C) treated with guaiacol and $\mathrm{H}_{2} \mathrm{O}_{2}$, we found that almost every part of the stem cells possesses POs. In addition, highly concentrated zones of POs were observed in epidermis and cell walls. Similar results regarding the localization of POs in epidermis and vascular tissues for Vicia faba roots were reported by Jensen [45].

Fig. 5 (A) indicates the control section made without guaiacol/ $/ \mathrm{H}_{2} \mathrm{O}_{2}$ treatments. As shown in (B), the oxidation of guaiacol was observed mainly in cell walls or adjacent areas, indicating relatively higher concentration zones of endogenous $\mathrm{H}_{2} \mathrm{O}_{2}$. Wang et al. [46] reported a similar result that histochemical localization of $\mathrm{H}_{2} \mathrm{O}_{2}$ in wheat plants was observed mainly in cell wall structure. It is considered that the results on the localizations of $\mathrm{POs}$ and $\mathrm{H}_{2} \mathrm{O}_{2}$ indicate the oxidation sites of EDCs by peroxidases. In addition, Fig. 6 illustrates the oxidation mechanisms proposed for EDCs degradation. It is known that endogenous $\mathrm{H}_{2} \mathrm{O}_{2}$ is produced through photochemical or respiration reaction in mitochondria [47]. Endogenous $\mathrm{H}_{2} \mathrm{O}_{2}$ is utilized for the oxidation of most phenolic EDCs catalyzed mainly by POs or biological Fenton reaction [19]. PCP is not oxidized by POs; however, in the presence of adequate concentrations of $\mathrm{Fe}^{2+}$, this compound is quickly oxidized by biological Fenton reaction through the consumption of endogenous $\mathrm{H}_{2} \mathrm{O}_{2}$ in aquatic plants [19, 25]. In our recent study [48], the $\mathrm{OH}$ radical formation via biological 
Fenton reaction in aquatic plants was experimentally confirmed by electron spin resonance analysis.

\subsection{Mass transfer rates and comparisons with a mass transfer model}

Assuming that overall removal rates of EDCs are controlled by mass transfer rates in liquid films, the specific removal rates defined by Equation (3) or the flux of EDCs can be calculated by:

$$
J_{E D C i}=k_{L i} C_{E D C i}
$$

Where, $J_{E D C i}$ is bulk or effluent concentration of component $i$ of EDCs.

Limiting current density of analyzed aquatic plants were $0.325 \times 10^{-3}\left(\mathrm{~A} / \mathrm{cm}^{2}\right)$ for $S$. polyrhiza, $0.431 \times 10^{-3}\left(\mathrm{~A} / \mathrm{cm}^{2}\right)$ for $L$. laevigatum, $0.56 \times 10^{-3}\left(\mathrm{~A} / \mathrm{cm}^{2}\right)$ for $C$. demersum and $0.712 \times 10^{-3}\left(\mathrm{~A} / \mathrm{cm}^{2}\right)$ for $N$. officinale, respectively. Thickness of liquid film analyzed by Equation (1) where an adjustment of the film thickness due to migration effect, according to the analytical procedure [35]. The liquid film thickness $(\delta)$ of analyzed aquatic plants were $195 \mu \mathrm{m}$ for $N$. officinale, $248 \mu \mathrm{m}$ for $C$. demersum, $322 \mu \mathrm{m}$ for $L$. laevigatum, and $427 \mu \mathrm{m}$ for S. polyrhiza, respectively. Therefore, the mass transfer

coefficient, $\mathrm{kLi}$ in Equation (6) can be estimated using molecular diffusion coefficient of EDCs $\left(D_{E D C i}\right)$ and analyzed liquid film thickness $(\delta)$ of aquatic plants.

Theoreticatlly calculated results of JEDCi are shown in Fig. 4 by solid lines in comparison with long-term continuous observed results. In the calculation, $\delta$ values were assumed to be the average value of analyzed aquatic plants (around $300 \mu \mathrm{m}$ in this study), while calculated fluxes for the smallest $\delta(195 \mu \mathrm{m})$ and the largest $(427 \mu \mathrm{m})$ are shown by dashed and dotted lines. Calculated results were in reasonably good agreement with observed results of BPA, 2,4-DCP, and 4-t-OP by aquatic plants (Fig. 4). On the other hand, plots for removal rates of PCP were displaced from theoretically calculated results as shown in Fig. 4(D). This happens because different types of aquatic plants show no capability to remove PCP from aqueous solutions (Fig. 2(D)), 
showing extremely low removal rates. Therefore, a more powerful oxidant reaction is needed to oxidize PCP from contaminated sites.

Fig. 7 shows the same comparisons of specific removal rates of E1, E2, and EE2. Observed specific rates were obtained from batch experiments (data not shown). Calculated removal rates for estrogens agreed well with observed results. From the comparisons in Figs. 4 and 7, it can be concluded that overall removal rates of EDCs

and estrogens by aquatic plants were controlled by mass transfer rates in liquid film, because enzymatic reaction rates by POs were 1 or 2 orders of magnitude larger than the mass transfer rates in liquid film.

\section{Conclusions}

In continuous experiments, except for PCP, EDCs such as BPA, 2,4-DCP, and 4-tOP were stably and concurrently removed by aquatic plants over 70 days. No significant effect of aquatic plant-bacteria association on the EDCs removal was observed.

POs were primal enzymes responsible for the BPA, 2,4-DCP, 4-t-OP, E1, E2, and EE2 removals. POs were located in almost every part of stem cells, while higher activities were found in cell walls of aquatic plants.

Specific removal rates of BPA, 2,4-DCP, 4-t-OP, E1, E2, and EE2 by POs were more than 2 orders of magnitude larger than those by aquatic plants.

Continuous long-term removal rates of BPA, 2,4-DCP and 4-t-OP by aquatic plants were in reasonably good agreement with theoretically calculated results developed based on an assumption that mass transfer in liquid film is a rate-limiting step.

\section{Acknowledgement}

This study was supported in part by Grant-in-Aid for challenging Exploratory Research (\#23656334), the Ministry of Education, Culture, Sports, Science and Technology (MEXT), Japan; and by Japan Science and Technology Agency (JST) and Japan International Cooperation Agency (JICA) through Science and Technology Research Partnership for Sustainable Development (SATREPS). 


\section{References}

[1] J.W. Birkett, J.N. Lester, Endocrine disrupters in wastewater and sludge treatment processes. Ed. J.W. Birkett, J.N. Lester, IWA Publishing, Lewis Publishers, London, UK, 2003.

[2] S. Kashiwada, H. Ishikawa, N. Miyamoto, Y. Ohnishi, Y. Magara, Fish test for endocrine-disruption and estimation of water quality of Japanese river, Water. Res. 36 (2002) 2161-2166.

[3] D.A. Crain, M. Eriksen, T. Iguchi, S. Jobling, H. Laufer, G.A. LeBlanc, L.J. Guillete $\mathrm{Jr}$, An ecological assessment of bisphenol-A: Evidence from comparative biology, Reprod. Toxic. 24 (2007) 225-239.

[4] V.K. Sharma, G.A.K. Anquandah, R.A. Yngard, H. Kim, J.F. Fekete, K. Bouzek, A.K. Ray, D. Golovko, Nonylphenol, octylphenol and bisphenol-A in the aquatic environment: A review and occurrence, fate, and treatment, J. Env. Sci. Helth. Part A 44 (2009) 423-442.

[5] J. Gao, L. Liu, X. Liu, H. Zhou, S. Huang, Z. Wang, Levels and spatial distribution of chlorophenols - 2,4-dichlorophenol, 2,4,6-trichlorophenol, and pentachlorophenol in surface water of China, Chemosph. 71 (2008) 1181-1187.

[6] C. Baronti, R. Curini, G. D’Ascenzo, A. Corcia, A. Gentili, R. Samperi, Monitoring natural and synthetic estrogens at activated sludge sewage treatment plants and in receiving river water, Envir. Sci. Tech. 34 (2000) 5059-5066.

[7] A. Yasuhara, H. Shiraishi, M. Nishikawa, T. Yamamoto, O. Nakasugi, T. Okumura, K. Kenmotsu, H. Fukui, M. Nagase, Y. Kawagoshi, Organic components in leachates from hazardous waste disposal sites, Waste. Manage. Res. 17 (1999) 186-197.

[8] T. Yamamoto, A. Yasuhara, H. Shiraishi, O. Nakasugi, Bisphenol A in hazardous waste landfill leachates, Chemosph. 42 (2001) 415-418.

[9] N. Caza, J.K. Bewtra, N. Biswas, K.E. Taylor, Removal of phenolic compounds from synthetic wastewater using soybean peroxidase, Water. Res. 33 (1999) 3012-3018.

[10] Y. Xuan, Y. Endo, K. Fujimoto, Oxidative degradation of bisphenol A by crude enzyme prepared from potato, J. Agric. Food. Chem. 50 (2002) 6575-6578.

[11] B. Schmidt, I. Schuphan, Metabolism of the environmental estrogen bisphenol A by plant cell suspension cultures, Chemosph. 49 (2002) 51-59. 
[12] G.D. Wang, Q.J. Li, B. Luo, X.Y. Chen, Ex planta phytoremediation of trichlorophenol and phenolic allelochemicals via an engineered secretory laccase, Nat. Biotech. 22 (2004) 893-897.

[13] T. Toyama, Y. Ning, H. Kumada, K. Sei, M. Ike, M. Fujita, Accelerated aromatic compounds degradation in aquatic environment by use of interaction between Spirodela polyrrhiza and bacteria in its rhizosphere, J. Biosci. Bioeng. 101 (2006) 346-353.

[14] W. Chai, H. Sakamaki, S. Kitanaka, M. Saito, A. Horiuchi, Biodegradation of bisphenol A by cultured cells of Caragana chamlaga, Biosci. Biotech. Biochemi. 67 (2003) 218-220.

[15] S. Roy, O. Hanninen, Pentachlorophenol: Uptake/elimination kinetics and metabolism in an aquatic plant, Eichhornia crassipes, Envir. Toxic. Chem. 13 (1994) 763-773.

[16] M.I. Noureddin, T. Furumoto, Y. Ishida, H. Fukui, Absorption and metabolism of bisphenol $A$, a possible endocrine disruptor, in the aquatic edible plant, Water Convolvulus (Ipomoea aquatica), Biosci. Biotech. Biochem. 68 (2004) 1398-1402.

[17] E. Pilon-Smits, Phytoremediation. Annu. Rev. Plant. Biol. 56 (2005) 15-39.

[18] S. Imai, A. Shiraishi, K. Gamo, I. Watanabe, H. Okuhata, H. Miyasaka, K. Ikeda, T. Bamba, K. Hirata, Removal of phenolic endocrine disruptors by Portulaca oleracea, J. Biosci. Bioeng. 103 (2007) 420-426.

[19] A.R. Reis, Y. Sakakibara, Enzymatic degradation of endocrine disrupting chemicals in aquatic plants and relations to biological Fenton reaction, Water. Sci. Tech. 66 (2012) 775-782.

[20] N. Nakajima, Y. Ohshima, S. Serizawa, T. Kouda, J.S. Edmonds, F. Shiraishi, M. Aono, A. Kudo, M. Tamaoki, H. Saji, M. Morita, Processing of bisphenol A by plant tissues: Glucosylation by cultured BY-2 cells and glucosylation/translocation by plants of Nicotiana tabacum. Plant. Cell. Physiol. 43 (2012) 1036-1042.

[21] K. Tabei, Y. Sakakibara, Removal of endocrine disrupting chemicals by phytoremediation, Paper M-17, Proceedings of $5^{\text {th }}$ International Conference on Remediation of Chlorinated and Recalcitrant Compounds, Monterey, CA; Battelle Press, 2006.

[22] C. Watanabe, A. Kashiwada, K. Matsuda, K. Yamada, Soybean peroxidasecatalyzed treatment and removal of BPA and bisphenol derivates from aqueous solutions, Envir. Prog. Sust. Ener. 30 (2011) 81-91. 
[23] W.X. Shi, L.Z. Wang, P.L. Diederik, N. Piet, L. Lens, Removal of estrone, 17aethinylestradiol, and 17ß-estradiol in algae and duckweed-based wastewater treatments systems. Environ. Sci. Pollut. Resear. 17 (2010) 824-833.

[24] T. Matsui, Y. Nomura, M. Takano, S. Imai, H. Nakayama, H. Miyasaka, H. Okuhata, S. Tanaka, H. Matsuura, K. Harada, T. Bamba, K. Hirata, K. Kato, Molecular Cloning and Partial Characterization of a Peroxidase Gene Expressed in the Roots of Portulaca oleracea cv., One Potentially Useful in the Remediation of Phenolic Pollutants, Biosci. Biotech. Biochem. 75 (2011) 882-890.

[25] A.R. Reis, Y. Sakakibara, Continuous treatment of endocrine disrupting chemicals by aquatic plants and biological Fenton reaction, Japan. Societ. Civil Engin. Series G (Environ. Resear.) 67(2011) 725-734.

[26] M.Yoshida, H. Ono, Y. Mori, Y. Chuda, M. Mori, Oxigenation of bisphenol A to quinones by polyphenol oxidase in vegetables, J. Agric. Food Chem. 50 (2002) 4377-4381.

[27] H. Kaneda, T. Matsui, R. Tomiyasu, Y. Kuroda, Y. Higashimoto, T. Oda, H. Miyasaka, H. Okuhata, S. Tanaka, K. Harada, H. Matsuura, H. Nakayama, K. Kato, K. Hirata, Isolation of polyphenol oxidase genes from Portulaca oleracea and evaluation of their ability to metabolize endocrine-disrupting chemicals, Plant Biotech. 29 (2012) 391-357.

[28] E. Loffredo, C.E. Gattulo, A. Traversa, N. Senesi, Potential of various herbaceous species to remove the endocrine disruptor bisphenol A from aqueous media, Chemosph. 80 (2010) 1274-1280.

[29] H. Okuhata, K. Ikeda, H. M., S. Takahashi, T. Matsui, H. Nakayama, K. Kato, K. Hirata, Floricultural Salvia plants have a high ability to eliminate bisphenol A, J. Biosci. Bioeng. 110 (2010) 99-101.

[30] S. Saiyood, D. Inthorn, A.S. Vangnai, P. Thiravetyan, Phytoremediation of bisphenol A and total dissolved solids by the mangrove plant, Bruguiera gymnorhiza, Internat. J. Phytorem. 15 (2013) 427-438.

[31] H.L. Song, K. Nakano, T. Taniguchi, M. Nomura, O. Nishimura, Estrogen removal from treated municipal effluent in small-scale constructed wetland with different depth, Biores. Techn. 100 (2009) 2945-2951.

[32] C.E. Gatullo, A. Traversa, N. Senesi, E. Loffredo, Phytodecontamination of the endocrine disruptor 4-nonylphenol in water also in the presence of two natural organic fractions, Water. Air. Soil. Pollut. 23 (2012) 6035-6044. 
[33] F. Ghanati, A. Morita, H. Yokota, Induction of suberin and increase of lignin content by excess boron in Tabaco cells, Soil. Sci. Plant Nutr. 48 (2002) 357-364.

[34] W.H. Habig, M.J. Pabst, W.B. Jakoby, Glutathione S-transferases. The first enzymatic step in mercapturic acid formation, J. Biol. Chem. 249 (1974) 71307139.

[35] Y. Sakakibara, J.R. Flora, M.T. Suidan, P. Biswas, M. Kuroda, Measurement of mass transfer coefficients with an electrochemical method using dilute electrolyte solutions, Water. Resear. 28 (1994) 9-16.

[36] J. Newman, Effect of ionic migration on limiting currents, I\&EX Fundamentals 5 (1966) 525-529.

[37] C. Wilke, P. Chang, Correlation of diffusion coefficients in dilute solutions, AIChE Journal 1 (1955) 264-270.

[38] Japan Environmental Agency, Tentative investigation manual for endocrine disruptor chemicals (in Japanese), 1998.

[39] T. Okuda, Y. Matsuda, A. Yamanaka, S. Sagisaka, Abrupt increase in the level of hydrogen peroxide in leaves of winter wheat is caused by cold treatment, Plant Physiol. 97 (1) 1265-1267.

[40] IPCS (International Programme on Chemical Safety), Pentachlorophenol health safety guide. Health and Safety Guide 19 p.44, 1989.

[41] H. Hoang, N. Yu, T. Toyama, D. Inoue, K. Sei, M. Ike, Accelerated degradation of a variety of aromatic compounds by Spirodela polyrhiza-bacterial associations and contribution of root exudates released from S. polyrhiza, J. Environ. Sci. 22 (2010) 494-499.

[42] Z. Song, G. Huang, Toxic Effects of Pentachlorophenol on Lemna polyrhiza. Ecotoxicol. Environ. Safe. 66 (2007) 343-347.

[43] N. Nakajima, Y. Ohshima, S. Serizawa, T. Kouda, J.S. Edmonds, F. Shiraishi, M. Aono, A. Kudo, M. Tamaoki, H. Saji, M. Morita, Processing of bisphenol A by plant tissues: Glucosylation by cultured BY-2 cells and glucosylation/translocation by plants of Nicotiana tabacum, Plant. Cell. Physiol. 43 (2002) 1036-1042.

[44] H. Sakuyama, Y. Endo, K. Fujimoto, Y. Hatano, Oxidative degradation of alkylphenols by horseradish peroxidase, J. Biosci. Bioeng. 96 (2003) 227-231.

[45] W.A. Jensen, The histochemical localization of peroxidase in roots and its induction by indoleacetic acid, Plant. Physiol. 30 (1955) 426-432. 
[46] C.F. Wang, L.L. Huang, H.C. Zhang, Q.M. Han, H. Buchenauer, Z.S. Kang, Cytochemical localization of reactive oxygen species $\left(\mathrm{O}_{2}^{-}\right.$and $\left.\mathrm{H}_{2} \mathrm{O}_{2}\right)$ and peroxidase in the incompatible and compatible interation of wheat - Puccinia striiformis f. sp. Tritici, Physiol. Molec. Plant Pathol. 74 (2010) 221-229.

[47] A. Campa, Biological roles of plant peroxidases: Known and potential functions. In: Peroxidase in Chemistry a1991nd Biology. Ed. J. Everse, K.E. Everse, M.B. Grisham, Boca Raton, Florida, CRC Press, Vol.2, pp. 25-47.

[48] S. Nagahashi, Y. Sakakibara, Electron SPIN resonance analysis of Bio-Fenton process. In: The Sixth International Conference on Environmental Science and Technology, 25-29 ${ }^{\text {th }}$ June 2012, Houston, Texas, USA. 
Table 1. Former studies on EDCs treatments using plants, cells or plant enzymes.

\begin{tabular}{|c|c|c|c|c|c|}
\hline Plants or cells & EDCs* & Concentration & Enzyme* & Mode & Reference \\
\hline Eichhornia crassipes & $\mathrm{PCP}$ & $500 \mu \mathrm{g} / \mathrm{L}$ & GST & Batch & {$[4]$} \\
\hline Soybean & BPA, 2,4-DCP & $100-200 \mathrm{mg} / \mathrm{L}$ & POs & Batch & [9] \\
\hline Crude enzyme from potato & BPA & $120 \mathrm{mg} / \mathrm{L}$ & $\mathrm{PPO}$ & Batch & {$[10]$} \\
\hline Plant suspension cell & BPA & $1 \mathrm{mg} / \mathrm{L}$ & - & Batch & [11] \\
\hline Nicotiana tabacum & BPA & $10 \mathrm{mg} / \mathrm{L}$ & - & Batch & {$[12]$} \\
\hline Caragama chamlaga & BPA & $97 \mathrm{mg} / \mathrm{L}$ & - & Batch & [14] \\
\hline Ipomea aquatica & $\mathrm{BPA}$ & $5 \mathrm{mg} / \mathrm{L}$ & - & Batch & [16] \\
\hline Arabidopsis thaliana & 2,4,6-trichlorophenol & $2-8 \mathrm{mg} / \mathrm{L}$ & LAC & Batch & {$[12]$} \\
\hline Spirodela polyrhiza & 2,4-DCP, phenol & $5 \mathrm{mg} / \mathrm{L}$ & LAC & Batch & [13] \\
\hline Floating and submerged aquatic plants & BPA, 4-t-OP, NP & $10 \mu \mathrm{g} / \mathrm{L}$ & - & Batch and Continuous & [14] \\
\hline Portulaca oleracea & BPA, OP, NP & $5-114 \mathrm{mg} / \mathrm{L}$ & - & Batch & {$[18]$} \\
\hline Soybean & BPA & $2.5 \mathrm{mg} / \mathrm{L}$ & POs & Batch & {$[22]$} \\
\hline Lemma gibba & E1, E2, EE2 & $1-40 \mu \mathrm{g} / \mathrm{L}$ & - & Batch and Continuous & {$[23]$} \\
\hline Portulaca oleracea & $\mathrm{BPA}, \mathrm{OP}, \mathrm{NP}, \mathrm{E} 2$ & $7-13 \mathrm{mg} / \mathrm{L}$ & POs & Batch & [24] \\
\hline Floating and submerged aquatic plants & BPA, 4-t-OP, 2,4-DCP & $100 \mu \mathrm{g} / \mathrm{L}$ & POs & Continuous & [19] \\
\hline Floating and submerged aquatic plants & BPA, 4-t-OP, 2,4-DCP & $100 \mu \mathrm{g} / \mathrm{L}$ & - & Continous & {$[25]$} \\
\hline Fruits and vegetables & $\mathrm{BPA}$ & $100 \mathrm{mg} / \mathrm{L}$ & PPO & Batch & {$[26]$} \\
\hline Portulaca oleracea & BPA & $1.2 \mathrm{mg} / \mathrm{L}$ & PPO & Batch & {$[27]$} \\
\hline Radish, perennial ryegrass & BPA & $4.6-46 \mathrm{mg} / \mathrm{L}$ & - & Batch & [28] \\
\hline Floricultural Salvia plants & BPA & $1.2 \mathrm{mg} / \mathrm{L}$ & - & Batch & [29] \\
\hline Bruguiera gymnorhiza & BPA & $0.5-60 \mathrm{mg} / \mathrm{L}$ & - & Batch & {$[30]$} \\
\hline Phragmites australis & $\mathrm{E} 1, \mathrm{E} 2, \mathrm{EE} 2$ & $6 \mathrm{ng} / \mathrm{L}$ & - & Continuous & {$[31]$} \\
\hline Radish, ryegrass & NP & $1 \mathrm{mg} / \mathrm{L}$ & - & Batch & [32] \\
\hline
\end{tabular}

*Abbreviations of EDCs and enzymes are as follows:

EDCs - Endocrine disrupting chemicals, PCP - pentachlorophenol, BPA - bisphenol A, 2,4-DCP - 2,4-dichlorophenol, 4-t-OP - 4-tertoctylphenol, NP - nonylphenol, E1 - estrone, E2 - 17ß-estradiol, EE2 - 17 $\alpha$-ethinylestradiol, POs - peroxidases, PPO - polyphenol oxidase, LAC - plant laccase, GST - glutathione S-transferase. 
Table 2. Specific surface area, water content and enzyme activities in aquatic plants.

\begin{tabular}{|c|c|c|c|c|c|c|c|c|c|}
\hline Plant species & $\begin{array}{c}a \\
\mathrm{~cm}^{2} / \mathrm{g}-\mathrm{FW}\end{array}$ & $\begin{array}{c}\text { Water } \\
\text { content } \\
(\%)\end{array}$ & $\begin{array}{c}\text { SPO } \\
\text { U/g-FW }\end{array}$ & $\begin{array}{c}\text { IPO } \\
\text { U/g-FW }\end{array}$ & $\begin{array}{c}\text { СРО } \\
\text { U/g-FW }\end{array}$ & $\begin{array}{c}\text { PPO } \\
\text { U/g-FW }\end{array}$ & $\begin{array}{c}\text { GST } \\
\text { U/g-FW }\end{array}$ & $\begin{array}{c}\text { LAC } \\
\text { U/g-FW }\end{array}$ & $\begin{array}{c}\mathbf{H}_{2} \mathbf{O}_{2} \\
\mu \mathrm{mol} / \mathrm{kg}-\mathrm{FW}\end{array}$ \\
\hline C. demersum & 19.6 & 94.3 & 103 & 27.5 & 35.3 & 1.94 & 35.3 & 0.39 & 99.1 \\
\hline R. fluitans & 18.6 & 95.1 & 26.7 & 9.51 & 3.80 & 2.05 & 1.17 & 4.84 & 149 \\
\hline L. laevigatum & 24.5 & 94.8 & 13.9 & 7.10 & 4.34 & 3.41 & 0.50 & 1.12 & 611 \\
\hline S. polyrhiza & 47.4 & 93.6 & 9.51 & 2.34 & 0.13 & 1.67 & 4.19 & 1.13 & 301 \\
\hline H. verticillata & 21.3 & 94.4 & 6.06 & 0.47 & 0.21 & 2.43 & 1.69 & 0.84 & 365 \\
\hline F. antipyretica & 36.8 & 97.1 & 14.2 & 6.17 & 2.96 & 3.28 & 0.55 & 0.64 & 105 \\
\hline N. officinale & 17.9 & 95.7 & 6.22 & 7.18 & 0.91 & 1.44 & 0.70 & 1.18 & 459 \\
\hline P. oxyphyllus & 15.6 & 90.7 & 16.2 & 14.1 & 1.26 & 3.68 & 1.46 & 1.94 & 114 \\
\hline R. natans & 27.2 & 94.9 & 8.48 & 11.6 & 4.43 & 3.19 & 13.5 & 0.36 & 534 \\
\hline
\end{tabular}

*Abbreviations of enzymes are as follows:

$a$ : Specific surface area of plants, SPO: soluble peroxidase, IPO: ionically cell wall-bound peroxidase, CPO: covalently cell wall-bound peroxidase, PPO: polyphenol oxidase, GST: glutathione S-transferase, LAC: laccase, $\mathrm{H}_{2} \mathrm{O}_{2}$ : hydrogen peroxide 
Table 3. Removals of phenolic EDCs and estrogens by different crude enzymes.

\begin{tabular}{|c|c|c|c|c|c|c|c|c|}
\hline \multirow[t]{2}{*}{ Crude enzymes ${ }^{+}$} & \multirow[t]{2}{*}{ Plant Species } & \multicolumn{7}{|c|}{ Removal efficiency (\%) } \\
\hline & & BPA & 2,4-DCP & 4-t-OP & PCP & E1 & E2 & EE2 \\
\hline \multirow{4}{*}{ SPO* } & C. demersum & 99.2 & 80.9 & 98.1 & 14.2 & 100 & 100 & 100 \\
\hline & R. fluitans & 99.5 & 99.2 & 99.3 & 5.80 & 100 & 100 & 100 \\
\hline & L. laevigatum & 88.5 & 26.2 & 76.6 & 8.22 & 82.6 & 95.5 & 100 \\
\hline & S. polyrhiza & 98.5 & 35.3 & 87.8 & 24.4 & 65.2 & 95.7 & 100 \\
\hline \multirow{4}{*}{ IPO* } & C. demersum & 99.1 & 69.5 & 95.6 & 26.2 & 100 & 100 & 100 \\
\hline & R. fluitans & 96.9 & 76.1 & 94.9 & 50.8 & 81.2 & 87.3 & 100 \\
\hline & L. laevigatum & 4.79 & 57.3 & 30.1 & 36.1 & 89.4 & 83.6 & 86.1 \\
\hline & S. polyrhiza & 65.8 & 40.1 & 59.4 & 30.3 & 87.4 & 95.7 & 93.2 \\
\hline \multirow{4}{*}{$\mathrm{CPO}^{*}$} & C. demersum & 90.6 & 52.9 & 78.9 & 34.7 & 100 & 100 & 100 \\
\hline & R. fluitans & 97.6 & 75.1 & 96.6 & 46.9 & 84.2 & 95.7 & 100 \\
\hline & L. laevigatum & 2.24 & 38.2 & 24.8 & 50.7 & 38.9 & 32.9 & 69.9 \\
\hline & S. polyrhiza & 38.6 & 51.7 & 44.8 & 52.1 & 59.8 & 81.3 & 87.4 \\
\hline \multirow{4}{*}{ PPO** } & C. demersum & 4.06 & 47.4 & 31.1 & 30.1 & 8.23 & 3.37 & 13.3 \\
\hline & R. fluitans & 1.19 & 55.3 & 37.4 & 32.1 & 18.4 & 22.6 & 15.6 \\
\hline & L. laevigatum & 89.9 & 44.9 & 79.8 & 26.6 & 2.68 & 29.4 & 29.9 \\
\hline & S. polyrhiza & 93.4 & 35.9 & 70.2 & 25.1 & 28.6 & 56.3 & 83.4 \\
\hline \multirow{4}{*}{$\mathrm{GST}^{* *}$} & C. demersum & 16.2 & 19.6 & 18.6 & 8.48 & 1.32 & 9.75 & 3.39 \\
\hline & R. fluitans & 9.99 & 5.55 & 2.80 & 2.05 & 1.43 & 12.7 & 2.38 \\
\hline & L. laevigatum & 8.43 & 10.4 & 7.40 & 2.63 & 0.24 & 2.72 & 4.06 \\
\hline & S. polyrhiza & 13.2 & 6.27 & 3.84 & 7.52 & 0.87 & 1.24 & 16.1 \\
\hline \multirow{4}{*}{$\mathrm{LAC}^{* * *}$} & C. demersum & 10.4 & 8.86 & 10.6 & 5.38 & 0 & 20.5 & 0.14 \\
\hline & R. fluitans & 15.5 & 19.9 & 20.6 & 11.4 & 0.12 & 31.1 & 31.1 \\
\hline & L. laevigatum & 7.15 & 4.83 & 10.2 & 7.08 & 2.77 & 26.4 & 43.1 \\
\hline & S. polyrhiza & 10.1 & 7.59 & 11.9 & 5.84 & 25.9 & 60.1 & 80.9 \\
\hline
\end{tabular}

Abbreviations of EDCs are as follows:

BPA - bisphenol A, 2,4-DCP - 2,4-dichlorophenol, 4-t-OP - 4-tert-octylphenol, PCP pentachlorophenol, E1 - estrone, E2 - 17ß-estradiol, EE2 - 17 $\alpha$-ethinylestradiol,

+ Crude enzyme concentrations correspond to $10 \mathrm{~g}-\mathrm{FW} / \mathrm{L}$

* Reaction time and $\mathrm{H}_{2} \mathrm{O}_{2}$ concentration were set at $3 \mathrm{~h}$ and $0.15 \mathrm{mM}$, respectively

** Reaction time was set at $12 \mathrm{~h}$

*** Reaction time and dissolved oxygen concentration were set at $12 \mathrm{~h}$ and $10 \mathrm{mg} / \mathrm{L}$, respectively 


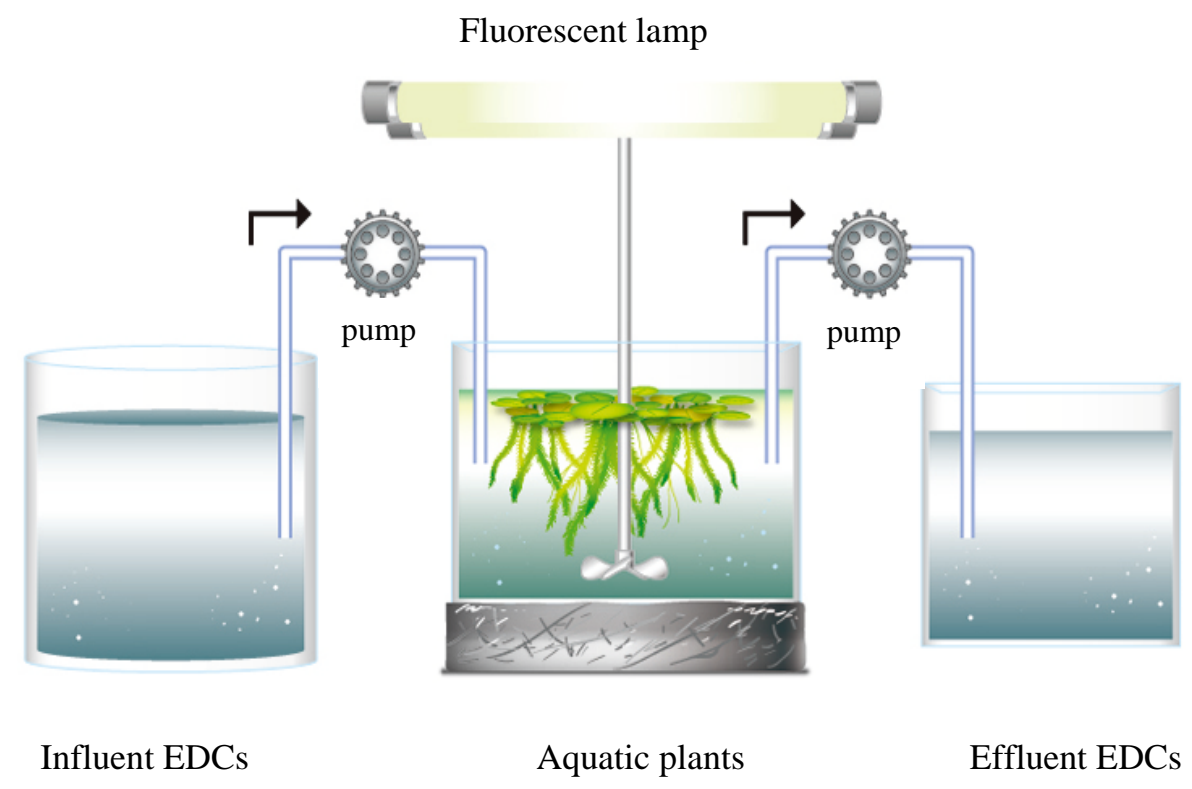

Fig. 1. Scheme of experimental apparatus. 


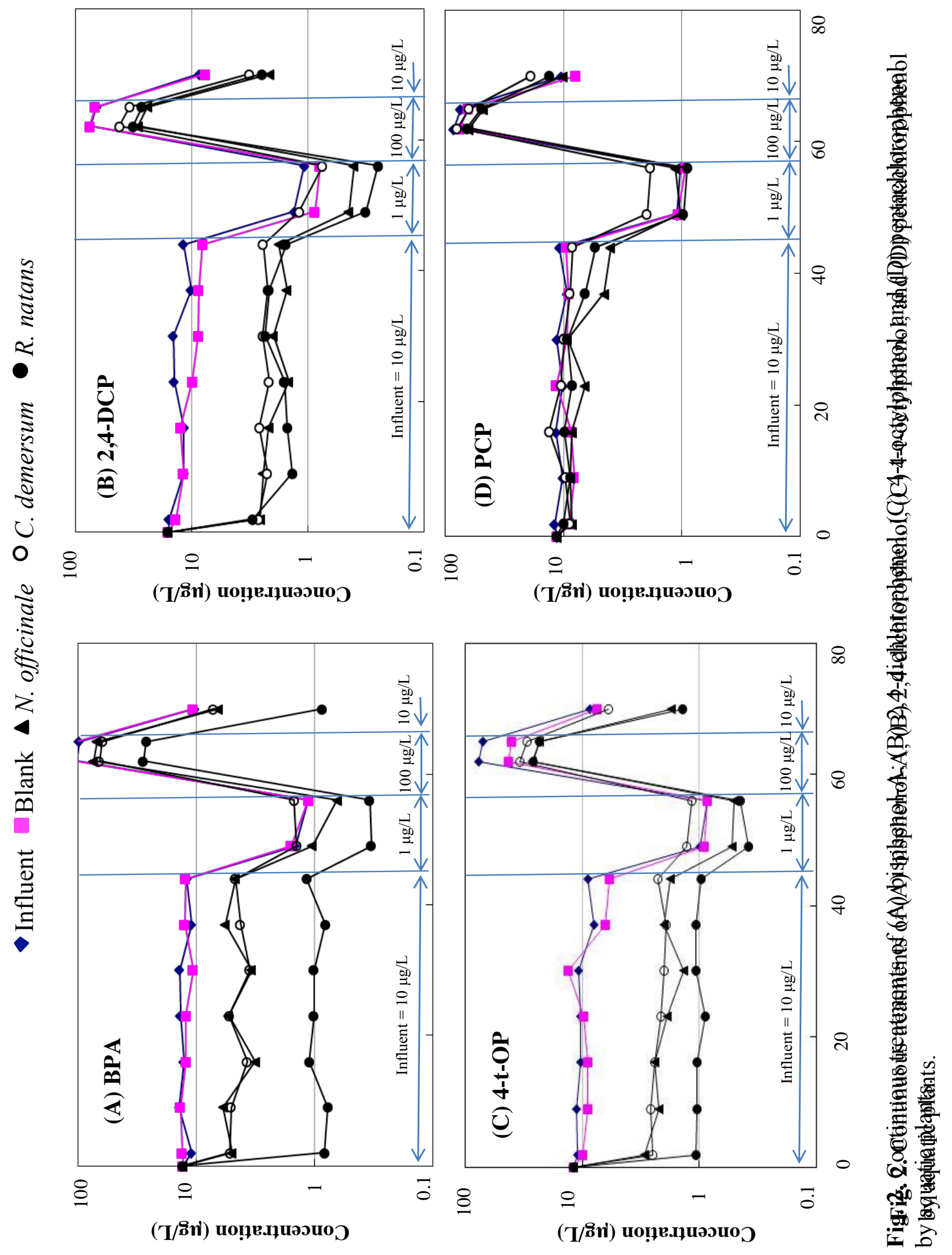


AS. polyrhiza (disinfected) $\triangle$ S. polyrhiza (undisinfected)

$\diamond$ L. aoukikusa(disinfected) $\diamond$ L. aoukikusa (undisinfected)
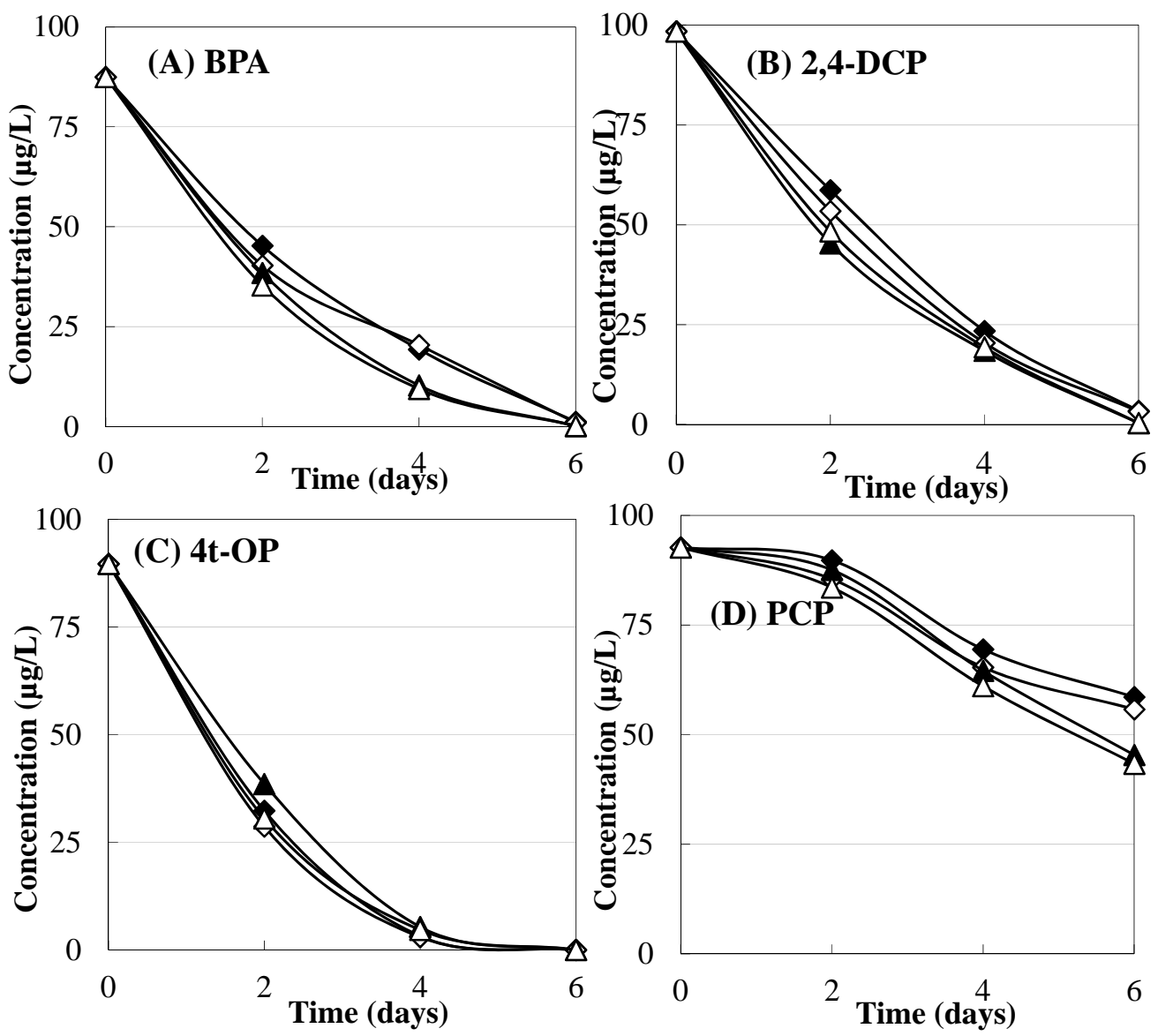

Fig. 3. Batch treatments of (A) bisphenol-A, (B) 2,4-dichlorophenol, (C) 4toctylphenol and (D) pentachlorophenol by disinfected and undisinfected aquatic plants. 
$\mathbf{\Delta}$. officinale $\bigcirc$ C. demersum $\bigcirc$. natans (This study)

$\square$ C. demersum $\diamond F$. antypiretica $\diamond$ L. laevigatum $\square$ L. aoukikusa $\triangle$ S. polyrhiza [25]

$\longrightarrow \delta(300 \mu \mathrm{m}) 1-\delta(195 \mu \mathrm{m}),-\delta(427 \mu \mathrm{m})$

(A) BPA

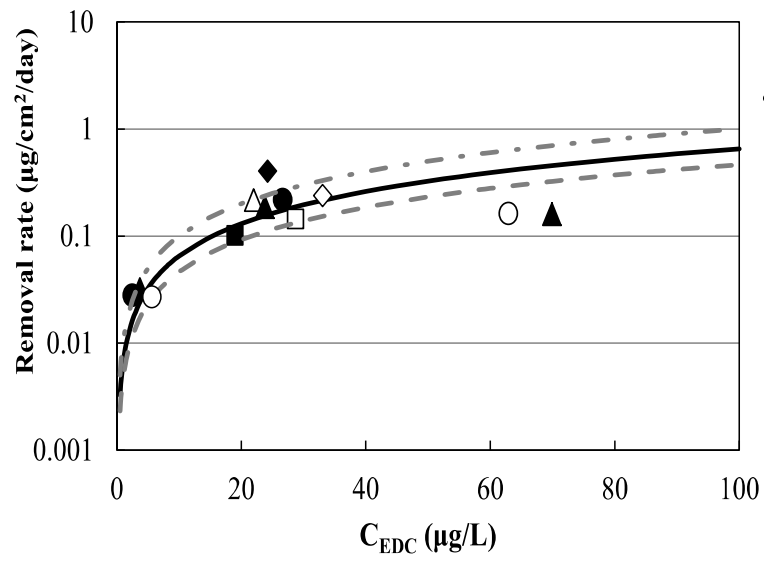

(C) 4-t-OP

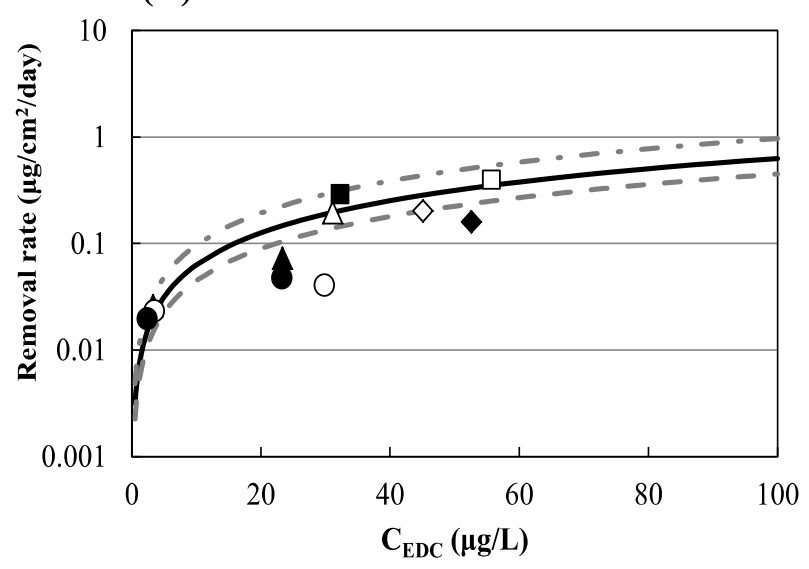

(B) 2,4-DCP

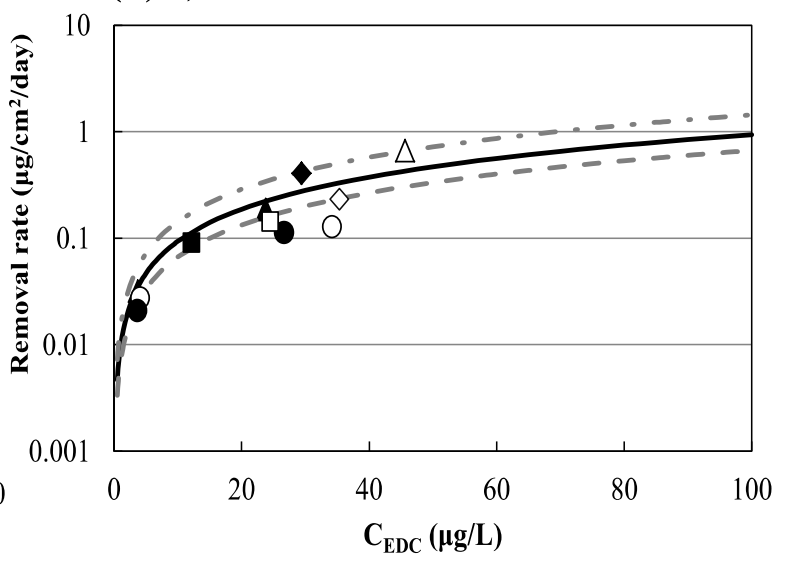

(D) PCP

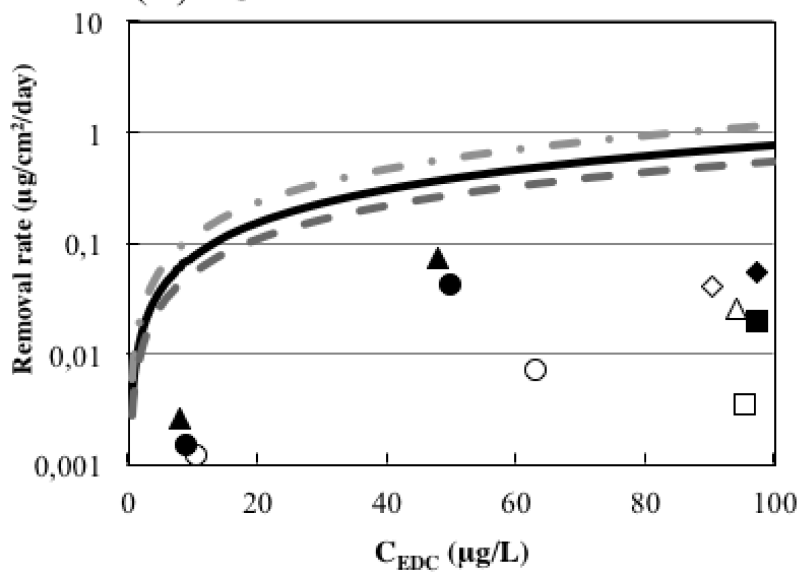

Fig. 4. Comparison of observed and calculated results for removal rates of (A) bisphenol A, (B) 2,4dichlorophenol, (C) 4-t-octylphenol and (D) pentachlorophenol. 


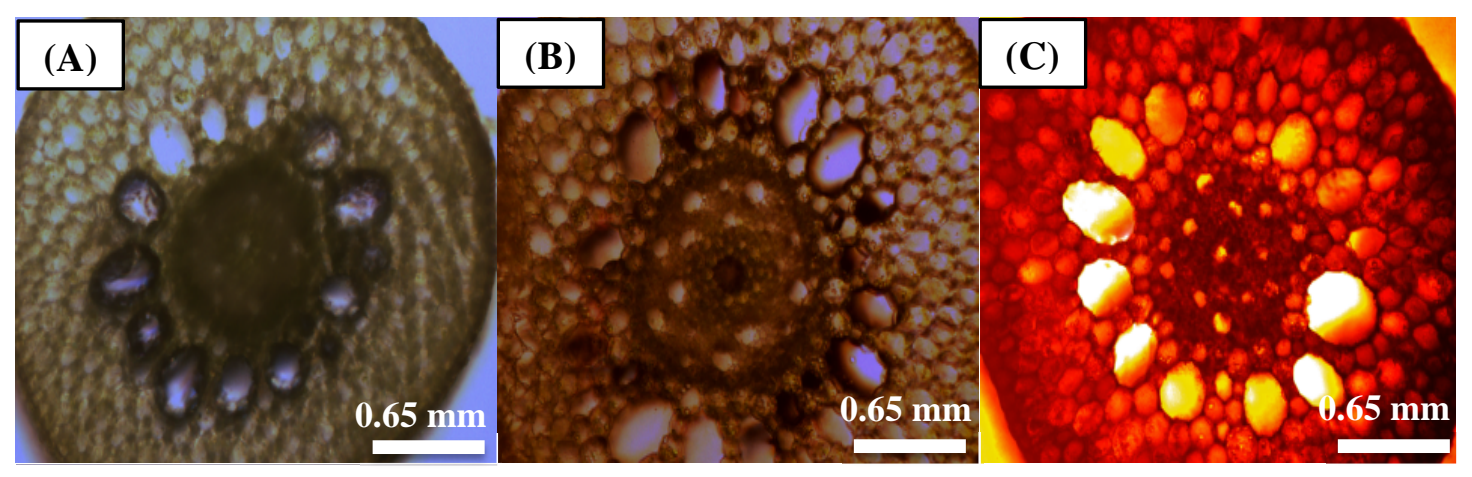

Fig. 5. Photomicrographs showing the localization of POs in the root with and without guaiacol $/ \mathrm{H}_{2} \mathrm{O}_{2}$ treatment: (A) stem of untreated $C$. demersum; (B) stem of $C$. demersum treated with guaiacol; (C) stem of $C$. demersum treated with guaiacol/ $\mathrm{H}_{2} \mathrm{O}_{2}$. 


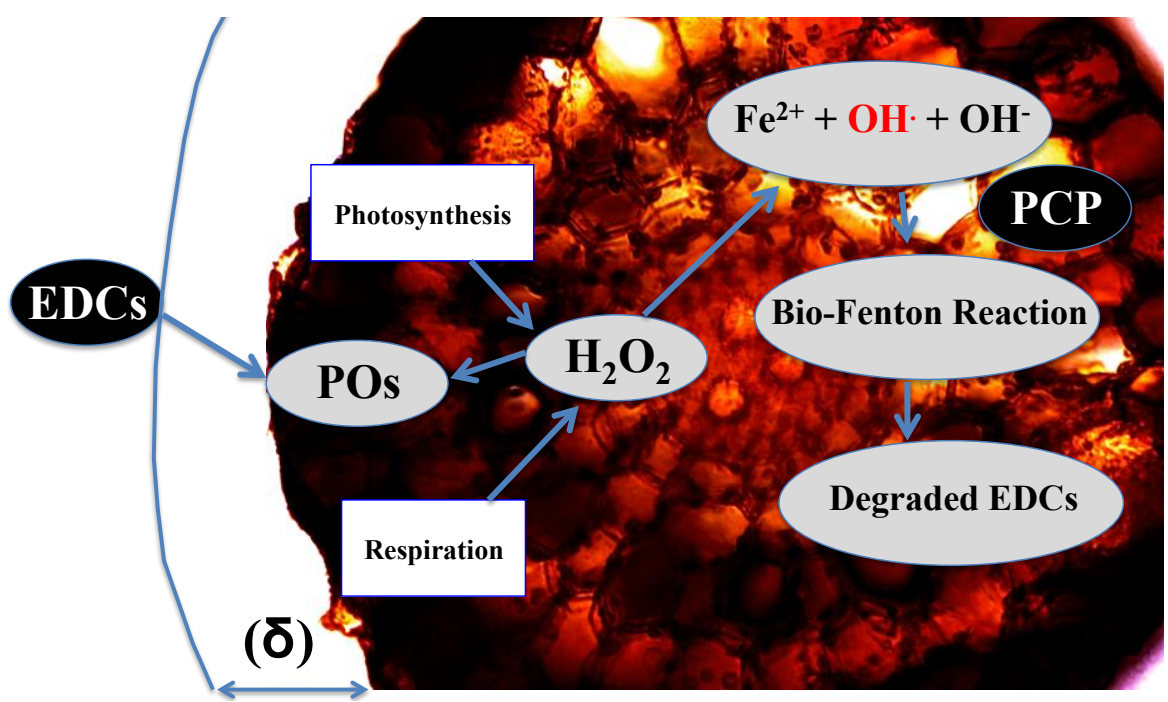

Fig. 6. A proposed mechanism for oxidations of EDCs and PCP in aquatic plants. 
$\diamond$ R. fluitans $\square$ S. polyrhiza $\bigcirc$ C. demersum $\triangle$. laevigatum

$\delta(300 \mu \mathrm{m}) 1-\cdot \delta(195 \mu \mathrm{m}),-\delta(427 \mu \mathrm{m})$

\section{(A) E1}

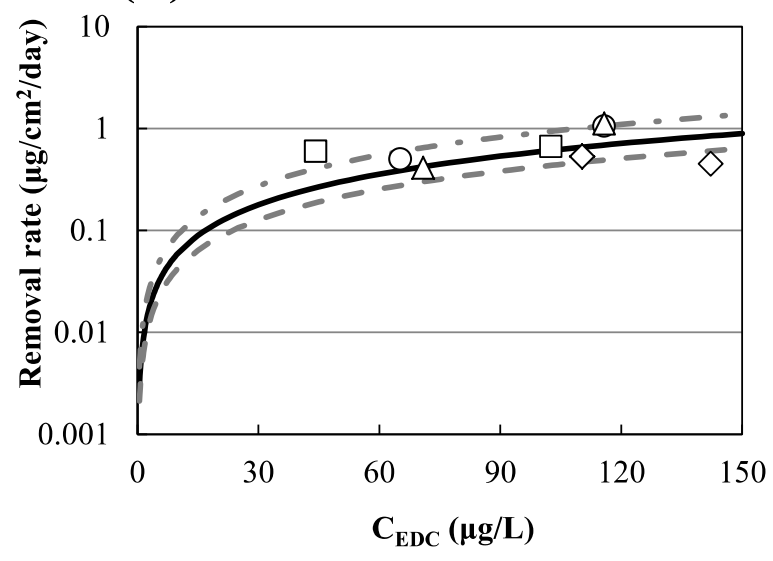

(B) E2

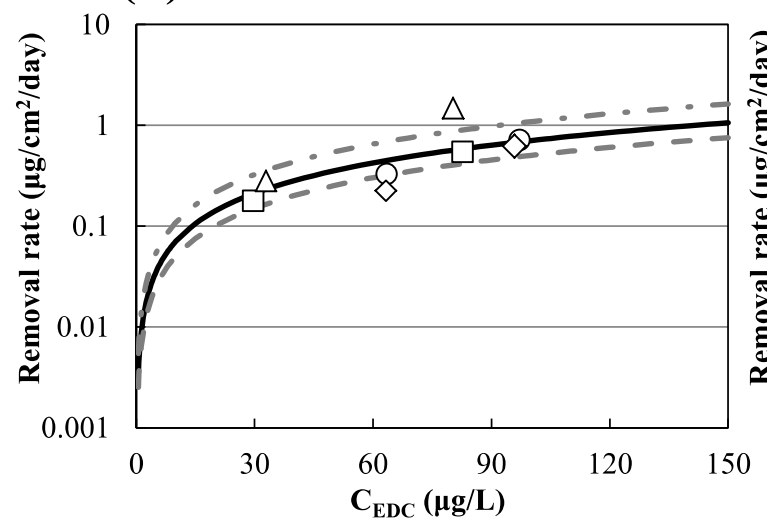

(C) EE2

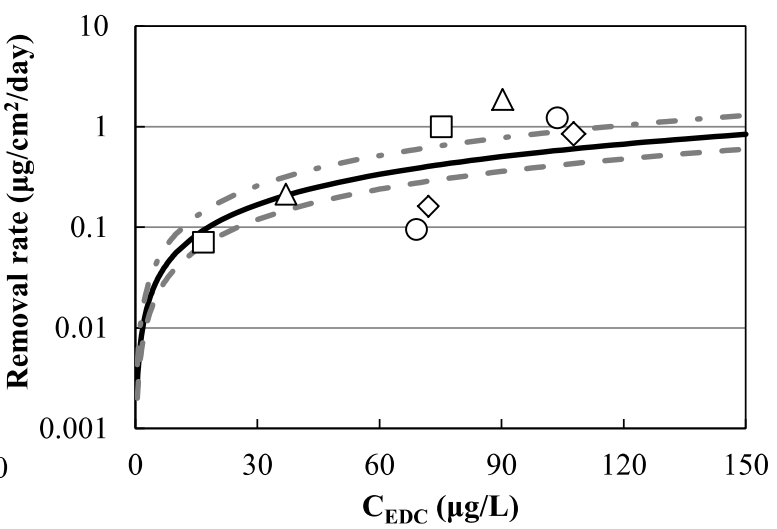

Fig. 7. Comparison of observed and calculated removal rates of (A) estrone, (B) 17ß-estradiol and (C) 17 -ethinylestradiol. 


\section{Graphical Abstract}

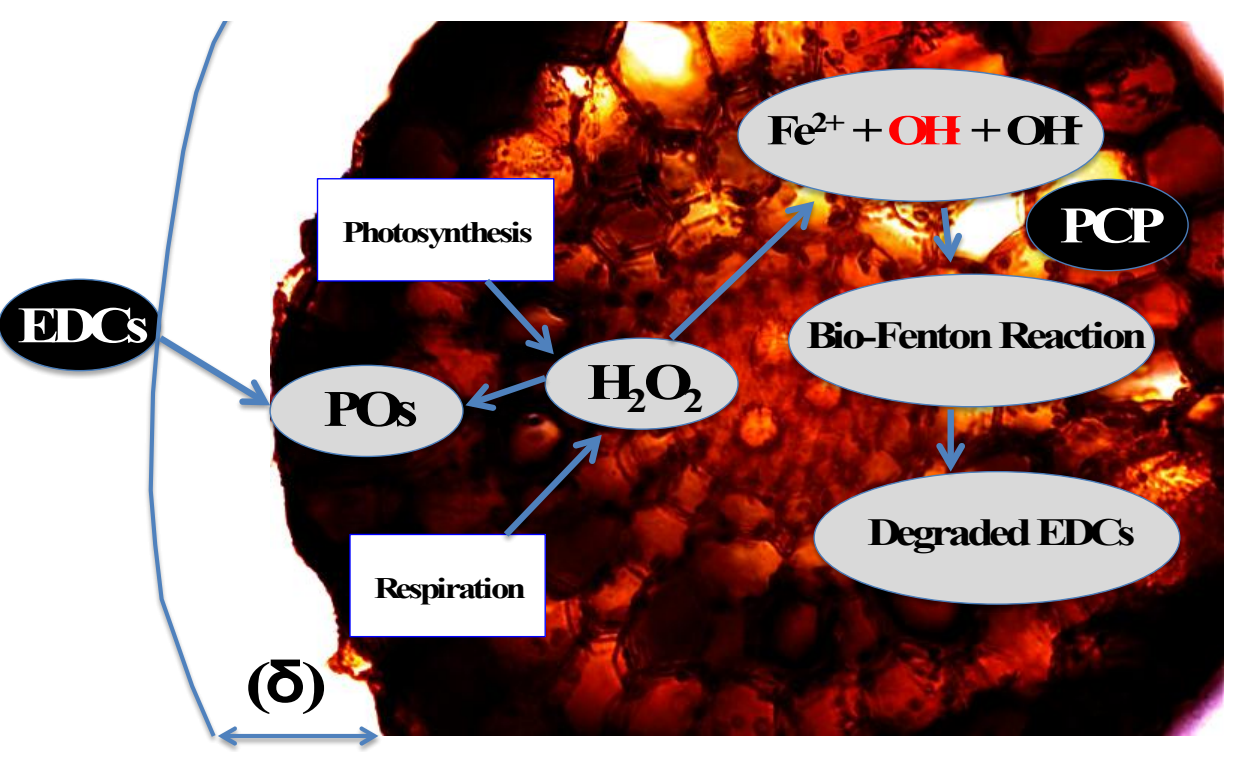

A proposed mechanism for oxidations of endocrine disrupting chemicals and persistent pollutants such as pentachlorophenol in aquatic plants. 